\title{
Collaborative Operations of Hospitality In- dustry during COVID-19 Lockdown and Strategic Approach with reference to Bangalore, India
}

\author{
Jamgade Sweety ${ }^{*}$ and Mathew Abby ${ }^{\dagger}$
}

\begin{abstract}
The outbreak of COVID-19 has brought the entire world to a massive crisis of human illness, fatality, insecurity in family, business instability, and the downfall of the economy, resulting in a huge number of job losses and pay cuts. The inadvertent consequences of COVID-19 started showing its effect in December 2019, and India started witnessing its spread by the end of February 2020 onwards. The focus of this study was to find the impact of COVID-19 on the hospitality industry in India before and during the first lockdown and its collaborative operations with special reference to Bangalore. The methodology incorporated in the study was the descriptive approach through the qualitative method, and the purposive sampling technique was utilised. It is evident that the hospitality industry was hit the hardest, as travel and stay of tourists plunged to an average of $-60 \%$ change of occupancy data compared to the same period in 2019 in India, according to the STR reports. Due to this VUCA (Volatility, Uncertainty, Complexity, and Ambiguity) environment, the hospitality industry has initiated some collaborative operations to render their services to society and
\end{abstract}

\footnotetext{
*Assistant Professor, Faculty of Hospitality Management \& Catering Technology (FHMCT), Ramaiah University of Applied Sciences, ,Bangalore, India; sweetyjamgade@msrchm.edu (Corresponding Author) † Dean, (FHMCT), Ramaiah University of Applied Sciences, Bangalore, India; dean.hc@msruas.ac.in
} 
generously assist the government bodies. It is observed that the strategic collaborative frameworks can reduce the industry jolts during such disasters.

Keywords: UNWTO, Collaborative, New Normal, Travel Advisory, VUCA, MICE

\section{Introduction}

\subsection{Impact of COVID-19 on the Hospitality Industry}

For a prosperous and productive society, health is the fundamental requirement, whereas panic and illness can stifle production, consumption, recreation, travel, and overall well-being (Marin B., 2018). The impact of this deadly virus on health and economic activities is much more than what was projected by the experts. (Ranasinghe et al., 2020) The United Nations World Tourism Organisation (UNWTO, 2020) estimated that there would be a decline of global international tourist arrivals by $20-30 \%$ in 2020 , leading to a reduction of US $\$ 30$ to $\$ 50$ billion in the receipts/earnings from Foreign Tourists Arrivals (FTA) but adding to it a deep plunge has been observed in 2020 and 2021. The tidal effect of this pandemic can be seen across the business segments of the hospitality industry, i.e., transportation, especially the airlines, cruises, railways, taxi, and auto services. Sectors of accommodations and food services such as hotels, resorts, hostels, paying guests, restaurants, etc., have been facing the brunt of the pandemic. The tourism business of travel agents and tour operators is going through a massive revenue loss in India. The events and exhibitions industry has come to a grinding halt (Kakkar A., 2020).

The earlier studies have noted that travel has been one of the factors behind the spread of the pandemic. According to Khan et al. (2009), as reported by the St. Michael's Hospital, due to air transmission, the epidemic can spread rapidly around the world and can become pandemic. As per the recorded data, due to the government imposed air travel restrictions, many of the airlines have limited or suspended their flights to many affected countries since February 2020 (Chinazzi et al., 2020). 
Due to these restrictions, a study by Senol et al. (April 2020) found that there were significant changes in market yields from January 02, 2020, to March 27, 2020, in general, but the sector where the decline occurred the most was airlines (Şenol, Zekai \& Zeren, 2020). According to OAG Aviation Worldwide, the airline industry worldwide has faced huge losses of up to $\$ 880$ billion and more due to the travel restrictions on international flights (Djeebat $\mathrm{H}$., 2020).

MICE (Meetings, Incentives, Conferences, and Exhibitions), also termed as Events industry, suffered owing to the ill consequences of COVID-19. Cancellations and postponing of events were the only resort for the hospitality segment (Congrex Team, 2020). The mega event of the Olympics 2020 was postponed to 2021. The COVID-19 pandemic has traumatized the global hospitality industry, with the bookings being cancelled and forced to stop reservations by large hotel chains and digital platforms of Online Travel Agents (OTA) in the Asian country(Folinas S, Metaxas T., 2020; $\mathrm{Wu}$, E. et al., 2010). Thus, the two key drivers that change the tourism industry are Climate change and global health emergencies of change in the world (Jamal T., Budke C., 2020).

\subsection{COVID-19 Impact on the Hospitality Industry in India:}

According to Jayajit Dash, India's travel and hospitality industry has incurred a revenue loss of more than 5 trillion rupees, battering 35-40 million direct and indirect jobs (Dash J., 2020). Due to the travel and visas restrictions, advisories, the enforcement of IPC section 144, i.e., restrictions of mass gatherings and lockdown in India, have impacted the revenue under branded, semi-organised and unorganised hotel sector reported by the HVS Anarock (2020), as shown in figure 1.

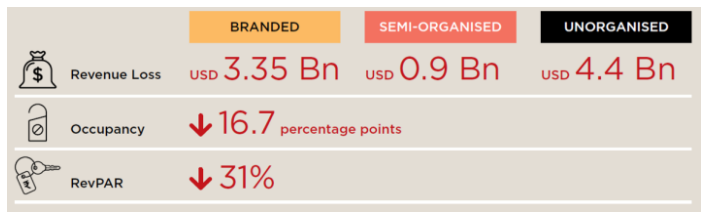

Fig 1. Impact on Indian Hotel Sector-Source: HVS Research; *Analysis based on data available as of March 23, 2020 
The STR report (2020) in figure 2 below indicates the impact of COVID-19 before and during the lockdown in India and the number of COVID-19 cases. It is observed that most of the hotels in India had $70 \%$ occupancy before the lockdown, and it plunged to $10 \%$ during the lockdown with the increase of COVID-19 positive cases.

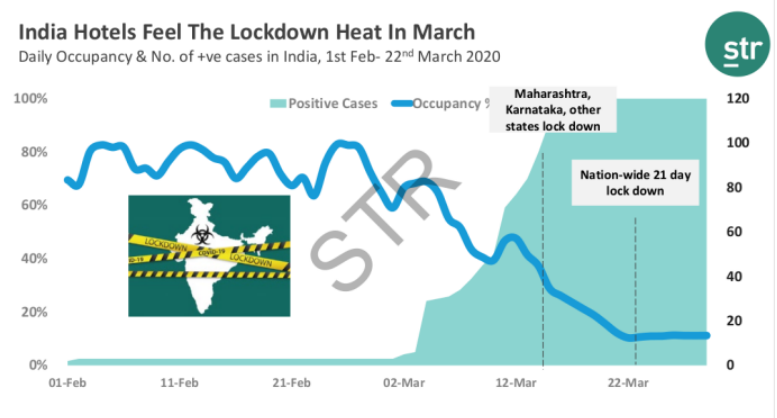

Fig 2. Hotel Occupancy and COVID-19 + cases $1^{\text {st }}$ Feb-22nd March 2020. Source: STR (2020)

Hotels downsized their operations and operated as quarantine facilities during the lockdown period. Figure 3 below by STR indicates the hotel occupancy drop in Bengaluru on an average from $80 \%$ to $20 \%$ before and during the lockdown, respectively.

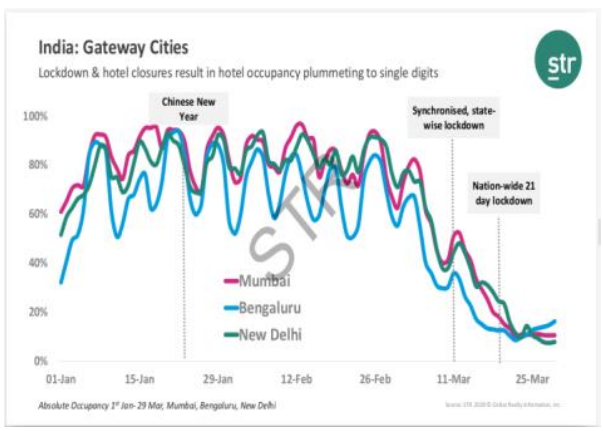

Fig. 3 Hotel Occupancy in Bengaluru before and during the Lockdown. Source: STR (2020) 


\section{Literature Review}

\subsection{Global Reflections and Collaborations during the Earlier Pandemics:}

The worldwide caution that surrounds the SARS-CoV-2 outbreak originates from the earlier pandemics such as the Spanish Influenza during 1918-1919 or similar to the 2003 SARS coronavirus epidemic (Lee et al., 2012). Mexico witnessed unknown influenza in March 2009, and they reported this as an outbreak of a novel influenza type virus called H1N1 swine flu to the Pan-American Health (Hubbert M., 2009). Bahamas managed the implementation of the response to the pandemic plan to H1N1 2009 with evidence-based practices. The collaboration between the emergency operation centre of the National Emergency Management Agency (NEMA) and that of the Ministry of Health allowed for a coordinated response among the agencies. The collaboration to increase the communications about the event by key tourism stakeholders and the emergency operation centre of the NEMA, the coordinated response among governmental and non-governmental agencies has strengthened Bahama's ability to react to the crisis in a timely manner (ET Hospitality World, 2020). The epidemic of SARS and H1N1 have demonstrated the preparedness of the hotel industry and infection control measures, but the hotel quarantine exposed the challenges and gaps in partnership (Neumann G., Noda, T. \& Kawaoka, Y. 2009). To optimise situational awareness and control, the united efforts of government officials, public health agencies, private service professionals, and political leaders are essential (Houghtton F., 2016, Henry B., 2018). A well-planned strategy is required to be implemented to tackle any epidemiologic crisis (Ahmed Z.A. et al., 2020).

\subsection{Collaborative Efforts of the Hospitality Industry in India with a Shared Vision of 'Indian Tourism Cares'}

Major hotel groups have come forward to provide respite to the stranded guests, frontline workers, and government agencies. The subsidiary of Tata Group conglomerate - Indian Hotels Company Limited (IHCL), also known as Taj group, has stepped in to distribute meals to Victoria Hospital medical staff in Bengaluru. Taj 
Public Service Welfare Trust (TPSWT), handled by TajSATS, provided meals to the migrant workers in Mumbai. During the lockdown period, 5000 meals were delivered on the first day, 10,000 on the second day, and 20,000 from the third day onwards. IHCL hotels offered rooms to the medical fraternity and local agencies. Ginger hotels are being used for quarantine purposes for the guests. Ginger hotels in Bangalore and Bhubaneswar worked in partnership with the Apollo Hospitals. Chalet Hotels rendered their services for the quarantine activity and provided meals to the police stations and employees of the Municipal Corporation in Mumbai. Radisson group provided dry ration kits, food packets to the underprivileged people and street animals. They also contributed to the CM's relief fund in the metro cities. Lalit group of Keshav Suri Foundation offered dry ration to the needy people and to the worst affected transgender through NGOs in Bangalore, Delhi, and Chandigarh with ration kits. Lalit hotel in Delhi has given 100 rooms to doctors working at GB Pant and Lok Nayak Hospital. ITC Hotels offered daily meals, quarantine facility, rooms for medical staffs, US embassy and expats in metro cities, provided shower caps to SMS hospital, hygiene products, and beach umbrellas to Police Station in Goa. Lemon Tree hotels provided quarantine facilities, rooms to MNC's foreign employees who are stranded. In partnership with Apollo hospitals, Lemon Tree provided complete facilities for isolation under the Project Stay I (Stay Isolated) with the state governments and city authorities. Leela group of hotels cooperated with the local authorities for the delivery of "care packages' consisting of daily need food and hygiene products for the underprivileged families. Sarovar group of hotels, in collaboration with the local authorities, prepared 250 meals per day to distribute to the front line workers and poor and provided groceries to old age homes. Small hotels and restaurants took care of their employees, stranded daily wage workers in their locality. The National Restaurant Association of India (NRAI) provided 10 million meals of $450 \mathrm{gm}$ of two meals pack for people in desperate need in all of the metro cities in India (Berry N., 2020).

Marriott Group of hotels located in close proximity to hospitals are in a unique position to help the hospital workers, employees of supermarkets, and military forces who are required to stay close to 
the hotel or are stranded to go back to their home. They contributed ration kits, cooked meals, hygiene kits, protective gear, and sanitising and cleaning products to the health fraternity and other frontline workers (Govil N. 2020). The guests having the membership can also contribute through Marriott Bonvoy's Giving Platform by donating the membership points to relief organizations such as UNICEF, Red Crescent Societies, and World Central Kitchen that are active in COVID-19 responses around the world (Sorenson A., 2020). The case of Amazon and its corporate social responsibilities during the pandemic to deliver groceries by expanding its online business is well explained by Aguinis, H., Villamor, I., and Gabriel, K.P. (2020).

\section{Methodology}

This study utilized the descriptive research approach. The secondary data collected were through literature synthesis of research papers and news articles. Primary data was collected through qualitative methods of purposive sampling technique of representatives from various hospitality sectors in Bangalore. The representatives were the employees from the top-level management of six sectors of the hospitality industry, i.e., luxury hotel, budget hotel, cloud kitchen, facility management services, Bangalore International Airport Limited, and travel agencies of Bangalore. Two respondents from each of the six sectors responded, totalling twelve qualitative responses. The responses were mostly collected through online meetings and structured telephonic interviews during the total lockdown period. The recordings were transcribed. A comprehensive study was developed which analysed the below-given research questions:

1. What was the global impact of COVID-19 on the hospitality industry?

2. How did the COVID-19 pandemic impact the hospitality industry before and after the lockdown in Bangalore, India?

3. What are the hospitality industry's various collaborative operations in serving society during the lockdown? 
4. How strategic collaborations/preparedness can reduce industry jolt?

Analysis of data was done by using the transcripts. An open coding mechanism was utilised for the collected data. Theme nodes were created on the above-given research question and codes with the help of N Vivo software.

\subsection{Data Analysis:}

The representatives were asked questions related to the business operations in terms of human resources and revenue utilization before and during the lockdown in Bangalore. Questions were asked to understand the collaborative measures undertaken to serve the society during the lockdown period and their suggestions. The following table 1 indicates the recorded responses from the representatives of various hospitality sectors related to business operations.

Table 1. Hospitality business before and during the COVID-19 lockdown

\begin{tabular}{lll}
\hline $\begin{array}{l}\text { Respondents(2 } \\
\text { from each sec- } \\
\text { tor) }\end{array}$ & $\begin{array}{l}\text { Q1-Business operations } \\
\text { before the lockdown }\end{array}$ & $\begin{array}{l}\text { Q2-Business operations dur- } \\
\text { ing the lockdown }\end{array}$ \\
\hline $\begin{array}{l}\text { R1- Luxury and } \\
\text { Representatives }\end{array}$ & $\begin{array}{l}\text { Mostly 80\% -90\% of } \\
\text { occupancy and were } \\
\text { close to meet the yearly } \\
\text { budgets. }\end{array}$ & $\begin{array}{l}\text { Plummeted to 10\%-20\% of } \\
\text { occupancy, yearly budgets } \\
\text { were not met, and Business } \\
\text { Contingency Plans were uti- } \\
\text { lised. }\end{array}$ \\
& $\begin{array}{l}\text { Operations were nor- } \\
\text { mal with regular SOPs } \\
\text { and full staff strength. }\end{array}$ & $\begin{array}{l}\text { It is a year's big revenue loss, } \\
\text { with no cash flow. Profit \& } \\
\text { loss zero revenue strategy. }\end{array}$ \\
& $\begin{array}{l}\text { Future bookings were } \\
\text { getting cancelled }\end{array}$ & $\begin{array}{l}\text { Only 10\% of the operational } \\
\text { workforce was utilised. }\end{array}$ \\
& $\begin{array}{l}\text { Mostly 77-85\% of occu- } \\
\text { pancy and events with }\end{array}$ & $\begin{array}{l}\text { Now few hotels are being } \\
\text { used for only quarantine ac- } \\
\text { tivity run by few managers. }\end{array}$ \\
$\begin{array}{l}\text { R2- Budget Ho- } \\
\text { full staff strength }\end{array}$ &
\end{tabular}




R3- Cloud
Kitchen Repre-
sentative

More than 10,000 of food deliveries per day

full human resource utilisation

Usual business operations.

All employees required.

R6- Travel Agency Representative

\section{Full HR strength}

Flights were operating as scheduled, but there were cancellations and a $30 \%$ drop in bookings.

Domestic tourism activities were as normal, cancellations of bookings were started.
The staff was given leaves, layoffs during the start of the lockdown, food deliveries were stalled due to the panic situation. Later the food deliveries were more due to the collaboration for the distribution of meals to the needy people, frontline workers.

More staffs are required now for the delivery.

The business was more in demand due to the deep cleaning and sanitation activity required at the offices, residential premises, and public places.

All employees required.

The flights are suspended until further notice as per the guidelines of the Ministry of Civil Aviation.

Staffs furloughed.

No Bookings, layoffs, and staff sent on leaves.

Staff required as usual.

The comparison of the open coded responses was enabled using $\mathrm{N}$ Vivo tools and is represented in figure 4 given below. It is clearly observed from the above table 1 and figure 4 that the hospitality business operations were usual before the outbreak of COVID-19 with the full utilisation of staff. It is found that the business was adversely affected during the complete lockdown phase with the 
major loss of revenue. The highly impacted were the human resources, as indicated in the dark blue line, due to the layoffs and furlough of staff. The business operations during the lockdown got inclined to quarantine and sanitation activities.

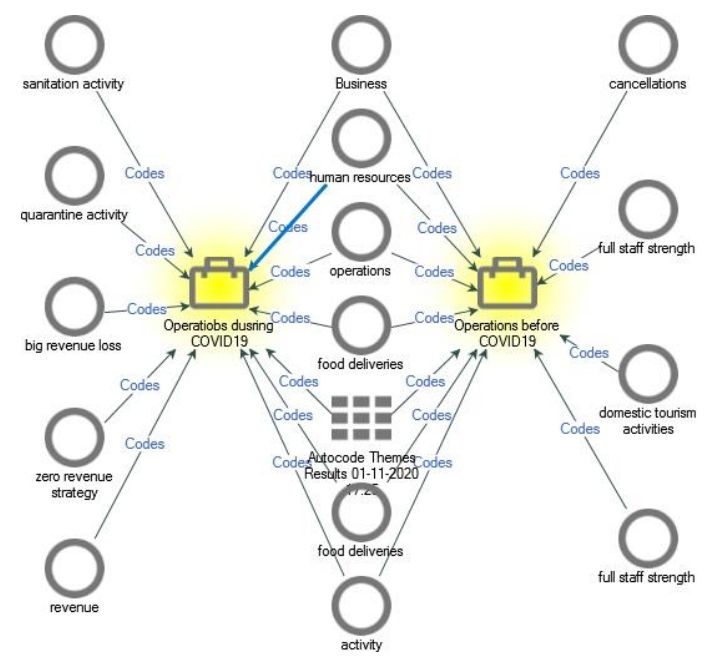

Fig. 4 Comparison of Hospitality Business Operations before and during COVID-19

According to a recent survey by HVS Anarock on 160 General Manager's sentiments in India, it was found that most of the hotel GM wanted to start their operations as early as permitted due to the abrupt ending of the hotel growth cycle and to reach the occupancy to 50\% in Q4 (ET Hospitality World, 2020).

Collaborative operations: The responses collected to understand the collaborative measures undertaken by the hospitality industry ensuing service to the society during the pandemic lockdown period are open coded and represented in the below figure 5. It was observed that all the hospitality sectors collaborated $100 \%$ to keep operating and contributing to humanity. Luxury and business hotels mostly collaborated with online delivery platforms for the distribution of meals to the needy and underprivileged. Many hotels associated with Apollo Hospitals arranged the stay of the frontline workers. They also collaborated with the city/ local administrative 
bodies in the isolation and quarantine stay of the expats and travellers.

Budget hotels helped the city/local administrative bodies in the distribution of meals and stored groceries to the needy and their employees who were stranded in association with the cloud kitchens and online delivery firms. Facility management services cooperated with the government and private firms in sanitising and cleaning activities at public places.

Bangalore International Airport Limited is associated with the central authorities, foreign embassies, and consulates for the repatriation flights, misting sanitizing, and deep cleaning of the airport, distribution of meals to the needy with the help of the housekeeping services, HMS, Taj Bangalore, SATIS dining staff. Travel agencies started with a travel awareness program and confidence building through online communications and webinars.

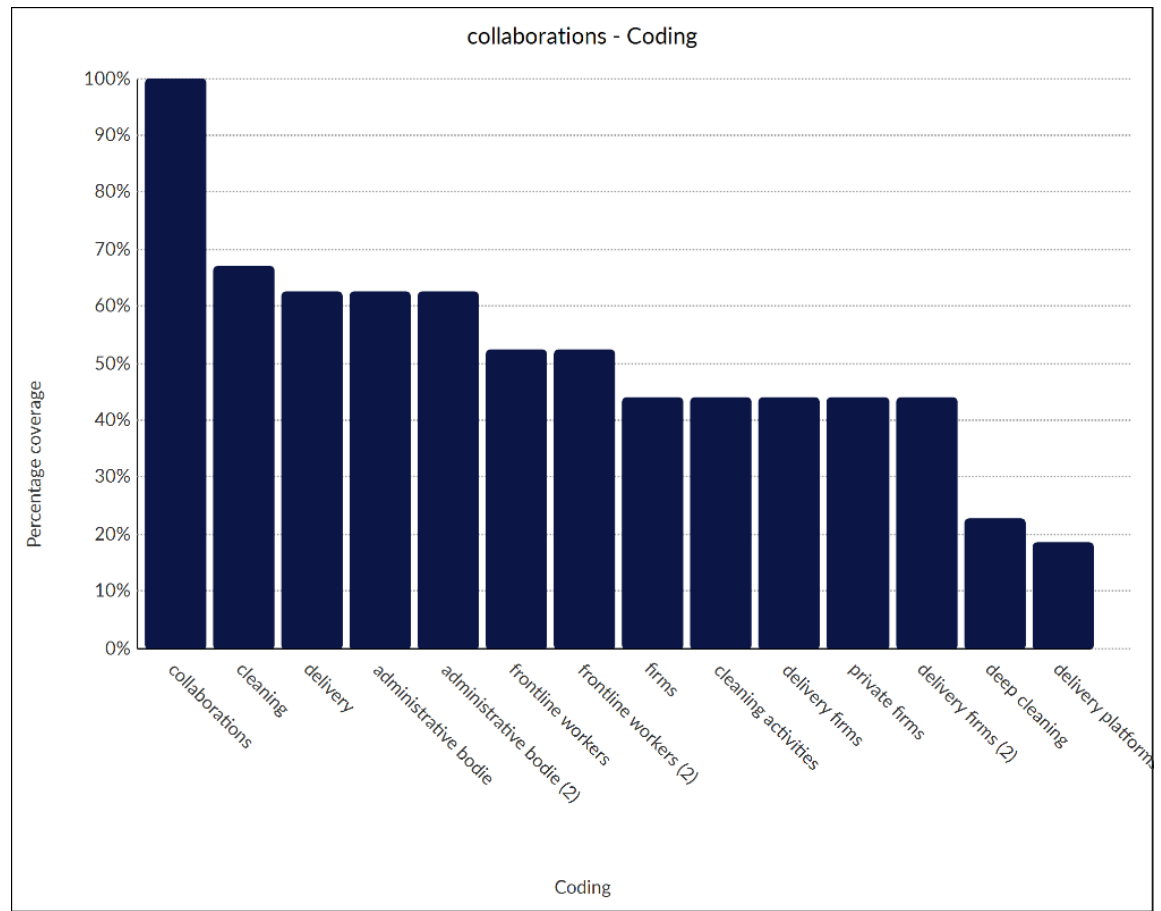

Fig 5. Collaborative Operations of Hospitality Industry during Covid-19 


\section{Conclusion}

Preparing and training for 'new normal' in this pandemic VUCA (Volatility, Uncertainty, Complexity, and Ambiguity) environment is a prerequisite to survive for any business. This study focussed on the three factors, i.e., the overall impact of the COVID-19 pandemic, its impact before and during the lockdown on the Indian hospitality industry, and its collaborative operations to serve the society during the pandemic in Bangalore, India. As observed, the impact of COVID -19 on the hospitality industry in the world was tremendous due to the amount of business and economic loss, human resource layoffs, and pay cuts. According to the STR reports, the hospitality industry in Bangalore, India, observed deep dive of an average of $-60 \%$ change of occupancy as compared to the same dates in 2019 due to the cancellation of bookings, suspension of hotels, travel agencies, and aviation business. The online food and other supply chain agencies saw a nominal closure during the initial phase of lockdown due to the chaotic environment and later had new normal business operations with the adherence to COVID-19 norms of health and safety. The facility management services saw a demand and splurge in their operations due to the massive requirement of housekeeping hygiene and sanitation practices everywhere. Most of the small players are struggling for their survival. Many closed outlets opted to put their staff on leaves, pay cuts, or layoffs. The WHO guidelines on International Travel and Health highlights the role of airlines as well as shipping companies together with that of tour operators and travel agents in limiting the spread of infectious disease across the borders in collaborations (World Health Organisation, International Travel \& Health). Thus travel industry was totally shut during the outbreak.

There were $100 \%$ collaborative activities performed by the hospitality industry professionals in association with the central/state/local administrative bodies. As represented in figure 6, most of the collaborations were to distribute meals to needy people during the complete lockdown in association with the online delivery services. Many hospitality, hospitals, and frontline workers have worked hand in hand to maintain hygiene, sanitation, and quarantine, and isolation facility during this pandemic. The collab- 
orative effort of the hospitality industry to offer free food, ration, and hygiene kits to the needy, frontline workers in collaboration with the state/city/local administrative bodies was incredible. The unanimous suggestion provided by the respondents was to have a collaborative approach of all the stakeholders of the government, public and private bodies to fight the COVID-19 together with a shared vision of 'Indian Tourism Cares'.

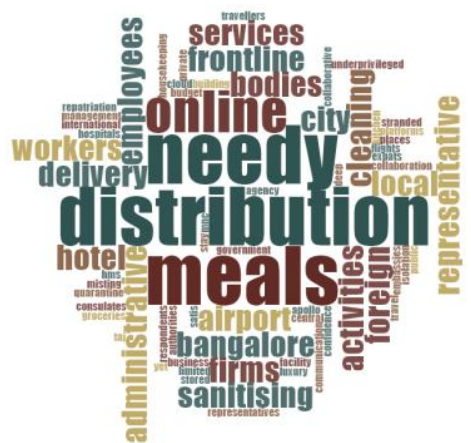

Fig 6. Wordcloud- Hospitality Industry Collaborative Activities during COVID-19 Lockdown

\subsection{Discussions and Suggestions:}

The future collaborative measures suggested by the representatives were redrawing of strategies and the horizontal collaboration of hospitality sectors such as hotels along with food deliveries, other supply chain platforms that could help in rendering food and service business. More use of technology and its collaboration with hospitality practices will enable the industry to follow the COVID19 preventive measures guidelines. There is a need for coordination mechanisms, use of screening, regular hygiene surveillance, and quarantine at hotel facilities which may help to mitigate the impact of such future events. Positive collaborations may bring about effective preparedness across the health and the tourism sectors (Hung KKC. et al., 2018). Focus on new entrepreneurial opportunities and innovations to effectively and efficiently embrace total hygiene and sanitation standards in the hospitality sector is demanded and needs to be studied. Service innovations are the consequences of such disruptive changes (Heinonen K., Strandvik T., 2020), leading to provisions of consumer needs, health, and safety. 
Proactively identifying risks, analyzing, and assessing risks strategically is the need of hospitality businesses (Bharwani S., Mathews D., 2012). The government stimulus to the hospitality industry should build confidence and assure economic recovery through funds for salary payment, service tax evasions, and subsidies. The National health, safety, and economic guidelines and mechanism should be in place to create confidence among their citizens. The Sustainable Development Goals-2030 of principles of decent work and equal opportunities should be encouraged by the employers, ensuring a safe and healthy working environment to minimise exposure to risks (World Tourism Organization, 2020). The use of PPE gears, sanitation, and cleaning equipment should be provided by the health and family welfare ministry to the service sectors so as to ensure that the health guidelines are practiced at work.

Pre-preparedness for the upcoming pandemic crisis, which is timely informed by WHO, should be integrated with the crisis management plans and SOPs of hospitality sectors and other businesses, enabling to minimize the dreadful economic and health impact. Multi-disciplinary collaborations and utilization of resources should be initiated by the officiating bodies for the seamless operations and coordination of social well-being at large.

\subsection{Limitations and Research Implications:}

The total closure of the cities during the phase-I lockdown was the limiting factor to reach the other respondents of the hospitality sectors such as entertainment, parks, etc. The interview was conducted during the initial phases of the panic grip, which was the very disturbing and unsettling phase of the pandemic outbreak.

This study has high implications for the public health control bodies and hospitality stakeholders to understand the strategic efforts that can be collaborated to mitigate the effects of any pandemic on society. It would enable the people involved to think tank and plan for the 'robust collaborative crisis management practices' so as to control the panic situations together in an effective form. The strategic suggestions would help in creating a framework of collaborative operations and a holistic approach for the public and private 
industry to work robustly for society, thus reducing the industry jolt in this VUCA world.

\section{References}

Aguinis, H., Villamor, I. and Gabriel, K.P. (2020). Understanding employee responses to COVID-19: a behavioral corporate social responsibility perspective. Management Research, 18(4), 421-438.

Ahmed Z.A., Fazeeda, B., Hassa R. (2020). Mitigation strategies to fight the COVID-19 pandemic-present, future and beyond. Journal of Health Research, 34(6), 2586-940X.

Berry N. (April 04, 2020). Tourism Cares: adopt a shared mission, give individual efforts an industry face, too! Retrieved from https://www.magzter.com/news/671/1869/042020/9sbj6

Bharwani S., Mathews D. (2012). Risk identification and analysis in the hospitality industry: practitioners' perspectives from India. Worldwide Hospitality and Tourism Themes, 4(5), 410-427(18).

Chinazzi, M., Davis, J. T., Ajelli, M., Gioannini, C., Litvinova, M., Merler, S., ... \& Vespignani, A. (2020). The effect of travel restrictions on the spread of the 2019 novel coronavirus (COVID-19) outbreak. Science, 368(6489), 395-400.

Team, C. (2020). Disruption in the business events industry; Rising to the challenges of Covid-19.

Dash J. (April 19, 2020).Covid-19 impact: Travel, hospitality stare at revenue loss of Rs 5 trillion. Retrieved from https://www.businessstandard.com/article/economy-policy/covid-19-impact-travel-hospitalitystare-at-revenue-loss-of-rs-5-trillion-120041800801_1.html

Djeebat H. (April 9, 2020). What is the impact of COVID-19 on the global hospitality industry? Retrieved from https://www.hospitalitynet.org/opinion/4098062.html

ET Hospitality World (May 07, 2020). 160 GMs survey: Here's what they said.

Available

from: https://hospitality.economictimes.indiatimes.com/news/160-gms-surveysheres-what-they-said/75594499

Folinas S., Metaxas T. (2020). Tourism the great patient of coronavirus COVID-2019. International Journal of Advanced Research, 8(4), 365-375.

Govil N. (May 04, 2020). Expect recovery tail to be shorter, working towards more smart and lean operations. Available from: http://www.tourismfirst.in/tourismfirst/expect-recovery-tail-to-be-shorterworking-towards-more-smart-and-lean-operations-neeraj-govil/

Heinonen, K. and Strandvik, T. (2020). Reframing service innovation: COVID-19 as a catalyst for imposed service innovation. Journal of Ser- 
vice Management, Vol. 32 No. 1. https://doi.org/10.1108/JOSM-05-20200161

Henry B. (2018). Canada's pandemic influenza preparedness: laboratory strategy. Can Commun Dis Rep, 44(1), 10-13.

Houghton, F., Del Monte, K., Glessner, D., Goff, J., Hopkins, E., Loney, K., \& Toms, J. (2016). Zombie pandemic preparedness: a cautionary observation. NZ Med J, 129(1432), 97-9.

Hubbert M. (2009). Travel and tourism under pandemic conditions - second review and preparation exercise. World Tourism Organisation, 3-4. Available from https://www.e-unwto.org/doi/abs/ 10.18111/9789284413355

Hung K. K. C., Mark C. K. M., Yeung M. P. S., Chan E. Y. Y., Graham C. A. (2018). The role of the hotel industry in the response to emerging epidemics: a case study of SARS in 2003 and H1N1 swine flu in 2009 in Hong Kong. Global Health, 14(1), 117.

HVS Anarock Report on COVID-19: Impact on the Indian Hotels Sector (April 10, 2020). Available from http://bwhotelier.businessworld.in/article/COVID-19-Impact-on-the-IndianHotels-Sector-A-Report-by-HVS/10-04-2020-188770/

Jamal T., Budke C. (2020). Tourism in a world with pandemics: localglobal responsibility and action. Journal of Tourism Futures, 6(2).

Kakkar A. (May 04, 2020). Covid-19 Impact and Revival of Travel and

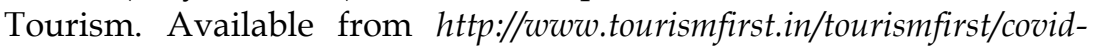
19-impact-and-revival-of-travel-and-tourism/

Khan, K. et al., (2009) Technical report, Bio. Diaspora Project, St Michael's Hospital, Toronto, Canada, Retrieved from: $h t t p: / / w w w 2$. biodiaspora.com/low_res.pdf

Lee et al. (2012). Globalization and Disease: The case of SARS. Asian Economic Papers, 3(1), 113-31.

Marin, B. (2018). Welfare in an idle society: reinventing retirement, work, wealth, health and welfare. Routledge, 1st Edn, 18-20.

Neumann G., Noda, T. \& Kawaoka, Y. (2009) Emergence and pandemic potential of swine-origin H1N1 influenza virus. Nature, 459(7249), 931939.

Ranasinghe, R., Damunupola, A., Wijesundara, S., Karunarathna, C., Nawarathna, D., Gamage, S., ... \& Idroos, A. A. (2020). Tourism after corona: Impacts of COVID 19 pandemic and way forward for tourism, hotel and mice industry in Sri Lanka. Hotel and Mice Industry in Sri Lanka (April 22, 2020).

Şenol, Z., \& ZEREN, F. (2020). Coronavirus (COVID-19) and stock markets: The effects of the pandemic on the global economy. Avrasya Sosyal ve Ekonomi Araştırmaları Dergisi, 7(4), 1-16. 
Sorenson A. (April, 2020) Marriott International Bonvoy. Available from https://news.marriott.com/news/2020/04/08/an-update-from-our-ceo

STR. (April 09, 2020). Webinar recording: COVID-19 hotel performance update. Central \& South Asia Edition.

UNWTO. (March 13, 2020). Tourism and COVID-19 Available from https://webunwto.s3.eu-west-1.amazonaws.com/s3fs-public/202004/COVID19_NewDS_.pdf

World Health Organisation. (n.d). Naming the coronavirus disease (COVID-19) and the virus that causes it. Available from https://www.who.int/emergencies/diseases/novel-coronavirus-2019/technicalguidance/naming-the-coronavirus-disease-(covid-2019)-and-the-virus-thatcauses-it

World Health Organization. (2012). International travel and health. Avail-

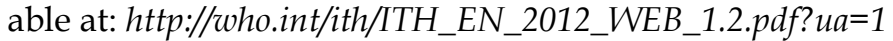

World Tourism Organization. (2020). Supporting Jobs and Economies through Travel \& Tourism - A Call for Action to Mitigate the SocioEconomic Impact of COVID-19 and Accelerate Recovery, UNWTO, Madrid, DOI:https://doi.org/10.18111/9789284421633

Worldometer (May 06, 2020). Available from https://www.worldometers.info/coronavirus/countries-wherecoronavirus-has-spread/

Wu, E. \& Law, Rob \& Jiang, B. (2010). The impact of infectious diseases on hotel occupancy rate based on independent component analysis. International Journal of Hospitality Management. 29, 751-753. 